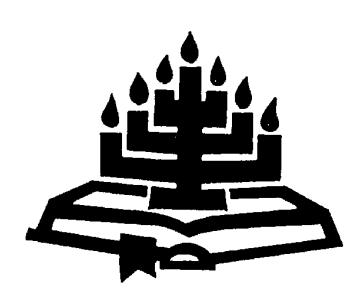

\title{
In the eyes of the beholder ... theopolitics and theopolitical leadership in 1 and 2 Chronicles
}

\author{
Henrietta Nel \\ Department of Biblical Studies \\ Extramural Division \\ University of Zululand \\ ISIPINGO \\ E-mail: henriet@yebo.co.za
}

\section{Abstract \\ In the eyes of the beholder ... theopolitics and theopolitical leadership in 1 and 2 Chronicles}

Theopolitics, a comprehensive subject that embraces all aspects of life, should not be confused with the antiquated conflict between church and church or between church and state. Theopolitics is about power and about who takes the lead in the struggle for supremacy.

The hypothesis of this article is that theopolitics consist of four major elements: i.e. a deity, the reporting of actual events, the mute, faceless masses and leadership. According to this premise leadership should be divided into visible leadership and an invisible leadership corps. As far as the visible leaders are concerned, their acts are "in the eye of the beholder", but they have no power, only the potential to manipulate the masses and the media. All power lies safely and securely in the hands of the invisible leadership. Without realising it themselves, the masses are mute and faceless. Invisible leadership, too, is mute and faceless, but that is due to personal preference, because its anonymity is the nucleus, the essence of its powerbase.

It is impossible to provide an immutable interpretation of the concept theopolitics within one article. The only objective of this article therefore is to contribute to the debate by highlighting a few of the problems relating to the role of theopolitical leadership. Unfortunately the quandary of theopolitical leadership is the uncertainty whether it is an unattainable dream about the past, a reality of today or a viable option for a successful tomorrow. 


\section{Introduction}

\subsection{Theos and politicos}

The concepts theopolitics and theopolitical leadership are as alive and well, as relevant today as in the past, as it will be in the future (cf. inter alia Reventlow et al., 1994; Gardner 1996)1. Inherent to the concept theopolitics are the two sciences theology and politics. From the dawn of history these two independent and distinct sciences have followed their separate yet inseparable ways. Unfortunately a tendency exists to confuse theopolitics with the age-old conflict between church and state, but the only consensus lies in the strategies employed. Biased reporting conveniently ignores their inseparability and, therefore, one should not be sidetracked by any apparent visible congruity between theopolitics (Hoffman, 1994:86) and theocracy (inter alia Abdalati, 1975:130-140; Donaldson, 1970:103-108; Keddie, 1972:17-257; MacIntyre, 1981; Le Roux, 1986:58-108; Nel, 1991).

Although a common phenomenon since antiquity, it is a fallacy that theopolitics is confined only to history books, sacred writings, to formal statements by religious fanatics. During the last decades of the twentieth century the highly manipulative and explosive nature of sacral-secular interaction has been emphasised by the global upsurge of religious fundamentalism in inter alia Israel, Egypt, Iraq, Afghanistan and even in so-called unbiased secular countries like the United States of America, France and South Africa. In the New South Africa of the late 1990s media and security spokespersons ascribe the activities of militant religious and semi-religious groups like Pagad (an acronym for People against Gangsterism and Drugs; cf. inter alia Le Roux and Nel, 1998:124), simply as the militant fundamentalism of religious groupings. However, political leanings and the objectives of leadership are never mentioned. In the same vein the theopolitics underlying the pronouncements of Thabo Mbeki concerning his vision of an African Renaissance, are not analysed. After all, as pure, unadulterated theopolitics, it does serve its objectives, namely to fill the masses with enthusiasm for their own heritage and for the future of a continent often described as a lost cause.

\subsection{Deification of politics and leadership}

For the purposes of this article theopolitics is regarded as a concept describing a process that consists of various elements. Although in this process the element theos does not necessarily refer to an actual deity, it does indicate that a Supreme Being, an object, ideology, theology, polity, creed is being deified.

1 Please note that for the scope of this article it was difficult to pinpoint only certain page numbers, because in most cases the book or article in its entirety was important. 
The obvious next question is who or what determines what should be deified and also the extent of the deification? The leaders or the led? This question emphasises a significant vacuity in the present study of theopolitics (cf. Reventlow et al., 1994), namely a definition and a critique of the role and the viability of leadership. It would appear as if this issue still represents virgin soil.

\section{Fundamental elements of theopolitics}

The postulate of this article is that there are four major elements inherent in any study of theopolitics: i.e. a deity, leadership, the masses and reporting, but not necessarily in that order. These four elements could be depicted diagrammatically as follows:

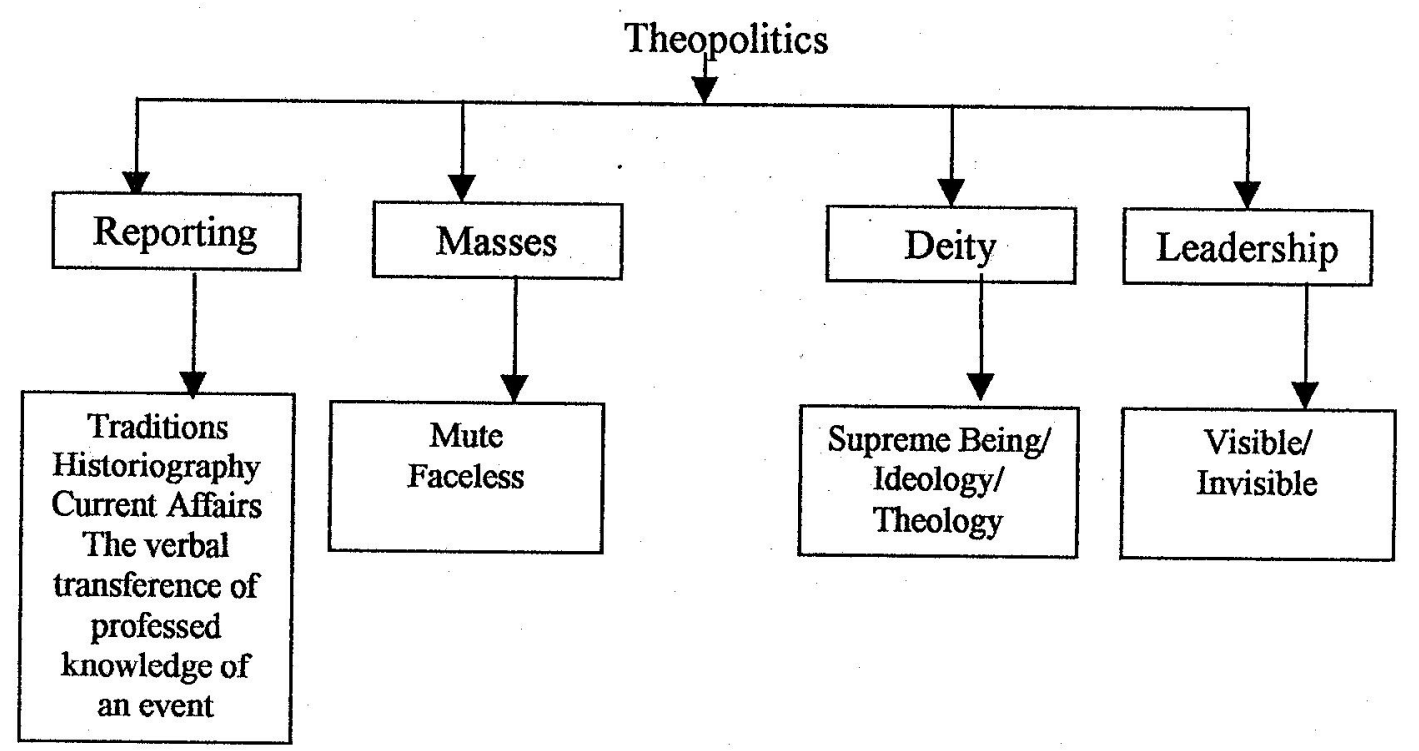

\subsection{Reporting}

In May 1789, Louis XVI summoned to Versailles a full meeting of the 'Estates General'.

The First Estate consisted of three hundred nobles.

The Second Estate, three hundred clergy.

The Third Estate, six hundred commoners.

Some years later, after the French Revolution, Edmund Burke, looking up at the Press Gallery of the House of Commons, said, 'Yonder sits the Fourth Estate, and they are more important than them all' (Archer, 1996:2).

\subsubsection{A fact of history: the Davidic dynasty}

This article accepts the dictum that historical matter belongs to the past and therefore it is irrecoverable, unrepeatable and beyond being altered (Asher, 1996:8-54.). Even though Bauval and Hancock (1997) claim to have achieved it 
with a computer reconstruction of the history of Egypt, the premise of this article is that it is impossible to arrange time, situation, events and role-players of the past for experimentation purposes. No historian dare risk being so presumptuous to proclaim that his/her knowledge is so comprehensive that no other conceivable alternate viewpoints are possible. On the other hand, a student of a particular epoch in history may propound an alternative point of view based inter alia upon scientific research, a different reading of a particular text, a new translation, the observation of particular current events. Unfortunately there always remain the inherent limitations occasioned by presuppositions. Even when the objective reality of a historical event could be guaranteed, the shortcomings of any type of reporting lies therein that intentional or unintentional biases of reporters too often create warped impressions of a past reality.

Transposed to the situation in the pre-exilic Southern Kingdom, it is an indisputable fact of history that it was ruled by a Davidic dynasty (2 Sam., 1 and 2 Kings, 1 and 2 Chr.). This historical reality is not disputed. What is questioned, is the bias of the Chronicler concerning the theopolitical validity of the rule of the individual Davidites. An excellent example is the negative portrayal of Manasseh who was such an "abject" ruler that he reigned for fiftyfive years! The Chronicler attempts to reconcile this unalterable historical fact by supplying his audience with his own version why there was a drastic change of policy in the later part of Manasseh's rule (cf. 2 Chr. 33:1-20). In line with the rest of his theopolitical tractate the Chronicler ascribes Manasseh's change of loyalties to a religious conversion, but was it a religious or a political conversion? If the latter is the case, then the assumption is that Manasseh's cleansing of the Jerusalem temple was done in submission to the theopolitical demands of those truly in control. But perhaps his conversion testifies to a new set of masters with a new deity or deities. The far-reaching implication of this premise is that only once he unquestioningly conformed to political demands, did he become theistically acceptable. This implies that the character and attributes of the Deity were unimportant and that what was crucial was whose politics did Manasseh practise at what point during his reign. Then the obvious question is why and to whom were the politics of the latter part of his rule so acceptable that the Chronicler found it necessary (or were compelled) to contribute to its deification?

\subsubsection{Historiography and the historiographer}

For the purposes of this article historiography is understood as a process in which a mere fact of the past is transformed into a fact of history (Asher, 1996). This implies that facts of history pass through a mental cognitive process that involves selection, interpretation and even perversion. The impetus behind this process is invariably an existing or an anticipated problematical issue that needs to be resolved or that requires sanctioning. Should we apply this dictum to the 
Chronicler's portrayal of Davidic history, he seemingly found it necessary to recount his interpretation of historical facts according to a preconceived perception of the requirements of successful leadership in the anticipated restoration process of post-exilic Judah. The expectations of the future necessitated the plotting of a blueprint for the success of the future. This magnum opus could be labelled theopolitical leadership. Unfortunately not even a historiographer of the calibre of the Chronicler can state unequivocally that the ultimate truth has been discovered about a fact of history and that no other option(s) exist (Elton, 1967:73-74). The crux of the matter is that there is no one verifiable truth and that despite the efforts of historiographers to present only the own biases, as time goes by, the facts of history always call for other and more interpretations.

\subsubsection{Partiality or impartiality of historiography}

Asher (1996:9-54) avers that the difference between facts about the past and facts of history relies upon an element of interpretation that the historian adds to the former in order to create the latter (cf. also Elton, 1976:76). In accordance with Asher, it is the contention of this article that a historiographer's conceptions of the prerequisites and presuppositions inherent to time, place and situation govern the understanding of the intrinsic meanings of the concepts partiality and impartiality. By transposing their own biased leanings on an already biased version, interpreters contribute to the corruption of historical facts. The results presented to the mundane are presuppositions of the interpreter intertwined with that of historiography often only lightly interspersed with historical facts. Unfortunately this process continues ad infinitum (cf. inter alia Snyman, 1991).

To illustrate the bias of historiography Amit (1994:29) quotes as example how dynastic changes forced historiographers to justify the choice of David as king by explaining Saul's disappearance from the scene as a religious inevitability. The inference is that circumstantial demands necessitated justification of the verity of Davidic leadership - and Saul becomes yet another victim of the theopolitics of the recorder of history.

This once again broaches the premise of this article, namely how do we differentiate between true and false leaders, who are the led and who or what constitutes the deity? Furthermore, to what extent do situational demands force leadership to use, abuse, manipulate and transform the perceptions of the faceless masses by means of a biased rendering of their deity's impact on the past, the present and the future? 


\subsubsection{Creating a paradigm}

According to a theopolitical reading of Chronicles, once a particular problem area is defined, historiographers attempt to steer future events by creating a paradigm based on interpretations of historical events. It is the viewpoint of this article that any paradigm can be equated to a map. Unfortunately a simple printing error can cause chaos, frustration and ineffectiveness to a traveller trying to reach a preconceived destination using a map for navigation purposes.

The indisputable and unalterable historical fact attested to in Chronicles is that there was a David, the founder of the Davidic dynasty. During a particular period this leader managed to coalesce into a nation a certain group of tribes located in a particular area, worshipping inter alia a specific deity. As king he established a dynasty that would last through a schism (2 Chr. 10), a fraternal war (2 Chr. 11:1-17), coups (2 Chr. 23; 34:8-35:19) and a usurpation (2 Chr. 22: 10-12). However, in the attempt to determine the validity of Davidic theopolitical leadership, the portrayal of his historicity as well as his leadership qualities depends solely upon the preconceptions and/or misconceptions and expectations of the historiographer. The truth is there, but the biases of reporting and reporters allowed historiography to turn a historical event into a precious theopolitical tool of manipulation (cf. inter alia Hattingh, 1999).

Constant references to David and continuous comparisons of the similarities and dissimilarities of his successors with his excellence, the Chronicler successfully transformed the rule of historical David into a paradigm of theopolitical leadership valid for all times. Thus the main characters, the facts of the past, are transposed into crucial pawns in the hands of skilful and well-trained manipulators, namely biased historiographers. The history of the Davidic dynasty is transformed into a paradigm of leadership with the power to turn a leader into a religious man of God, into an atheist, an agnostic, a hero or a coward. And so historiography turns a David, a Solomon, a Manasseh, an Amon, a Josiah into theopolitical rulers of Ortega y Gasset's (1930/1933) faceless masses. Translated into the words of Theodor Herzl (1895) the Chronicler, by turning the ideals of invisible leadership into a paradigm of leadership based on a biased view of historical facts, considered them (the envisioned dreams about the future) done!

However, should we equate the Chronicler's history of the Davidic dynasty with Covey's map, then the simple printing error could be identified as the bias of historiography that turned a man with human failings and who was a tool in the hands of the Hebron Levites (cf. Nel, 1997) into a flawless theopolitical leader par excellence. But in the eyes of the beholders this same paradigm was used to transform a discerning statesman into a scoundrel of ill repute (cf. the history of Manasseh in 2 Chr. 33:1-20). 
Although it is the postulate of this article that the above bias should be seen as a deliberate and an intentional distortion of historical facts to formulate theopolitical guidelines for post-exilic leadership, the masterplan was not based only on a theopolitical assessment of David as leader. Historiography turned the rule of his successors into the culmination of this paradigm. Therefore the rule of his successors is as essential as David's rule to the designing of a blueprint for leadership. The capability of his successors to conform to, to surpass or to deviate from the road of excellence ascribed to David should be seen as the results of the warped manipulated interpretation of historiography. The failure of his successors to comply with or to surpass the theopolitical excellence of David, was intended to serve as the map not to be followed in the future. In this way David's rule was transmuted into an example of and a basis for judgement of leadership for all ages and across all cultures.

\subsubsection{Cartographers}

Should we accept that the Davidic kings were merely the visible leaders/ ringleaders manipulated by a flawed paradigm, then the cartographers could be equated with the invisible, albeit the true leaders of the above-mentioned model of theopolitics. The next step would be to determine whether there is any extant evidence of a so-called invisible leadership corps who masterminded the development of this warped paradigm of Davidic leadership. It is the contention of this article that Chronicles abound with evidence concerning the existence of an invisible leadership corps who masterminded a flawed paradigm of visible leadership and that they probably came from the brotherhood of the Hebron Levites and (later) also from the Jerusalem cult officials (cf. inter alia $1 \mathrm{Chr}$. 11:1-3; 12:23-37; 2 Chr. 23-24; 34-35; Nel, 1997).

This conjecture leads to the next supposition, namely that the hidden message of the warped map is that unless the control of the visible leader corps by the invisible leadership is accepted, the same pitfalls that befell the pre-exilic Judahites await the returnees. The inevitable, but unanswered question is whether the objectives of these invisible leaders embraced the expectations of the faceless masses. As the concept people - as one of the components in a theocracy - is virtually left untouched by the Chronicler, it is the postulate of this article that the masses, mute and faceless, were of no consequence to leadership.

\subsubsection{Conclusion}

To reiterate - clothed in history -1 and 2 Chronicles present the mundane with a blueprint cemented in historiography for a successfully restored future, namely an all-encompassing theopolitical paradigm of leadership that functions on different levels of society. What is important is that the historiographer's opinion concerning leadership appears to be that the success or the ineffective- 
ness of the leader always reflects in the behaviour of the faceless masses in tow, and that the depravity and incompetence of the visible leadership-cum-masses were always depicted as obedience/disobedience to the deity.

\subsection{The deity}

\subsubsection{Definition}

In the context of this article deity is understood to refer to Yahweh, the God of Israel, the Supreme Being described as the Creator-God of the entire universe in the Book of Chronicles (cf. 1 Chr. 1-2; Chr. 36). As this has already been discussed in an earlier article by the author (Nel, 1992), no detailed study will be made of the concept deity or of the identity and the characteristics of Yahweh. However, according to the thesis of this article deification refers to the glorification of inter alia a person, belief, doctrine during the process described by the concept theopolitics.

\subsubsection{Chronicles and the deity of Davidic leadership}

The God portrayed in 1 and 2 Chronicles is no longer a nationalist God residing in a particular temple in a specified city. He is the God of Israel, of Jerusalem, of foreigners - even of the enemy (2 Chr. 36). Universal, omniscient and omnipotent, He reigns supreme even in the land of exile (cf. Ben-Sasson, 1976; Bright, 1972; Childs, 1985; Clements, 1989; Japhet, 1993; Roth, 1977; Smith, 1984; Nel, 1991; 1992). As supreme ruler of the theocracy outlined in detail by the Chronicler, He heads the government, rules the masses and acts as supervisor, guide, tutor and judge of kingship (cf. inter alia Japhet, 1993; Soggin, 1985). Chronicles interpret the success or failure of Davidic leadership as a Davidite's compliance or non-compliance with religious and political demands and ordinances ascribed to God. People and acts of leaders are deified in order to lend more credence to a particular historiographer's (the Chronicler's) viewpoints, ideals and fears of pitfalls awaiting future successful leadership of the restored exiles.

It is the contention of this article that in Chronicles it is not who or what the Supreme Being is that is at stake. In fact, it is the observance or non-observance of the deified political dictates of historiography (Chronicles) that clamours for judgement of Davidic leaders. The consequence of this line of reasoning is that the Supreme Being professed to be the God of the Davidites and their led, is that view of God that suits the requirements of the recorder and interpreter of preexilic leadership at a given time. In this process the skills and biases of a historiographer and/or recorder successfully transform a fact of history (Davidic kingship), into the deified politics or theopolitics of invisible, unmentioned leadership to create a paradigm for future leadership. In other words, by means of biased reporting, historiography, the invisible leadership endeavoured to 
control the outcome of the anticipated post-exilic restoration and reconstruction process. The ideals proclaimed by historiography become invaluable tools in the creation of a paradigm for impeccable leadership. To achieve the desired political results, politics are skilfully underplayed to the apparent advantage of an overemphasised deity. And without even realising it in the eyes of the beholders, a vision, an ideal is deified for the fulfilment of unmentioned objectives of leadership. An excellent present-day South African example is Thabo Mbeki's vision of an African Renaissance that has not yet dawned.

Therefore, apropos to the above, the viewpoint of this article is that Chronicles 23-27:4 is theopolitical writing par excellence. It was of no consequence to the Chronicler whether the deity portrayed in his historiography was the same God that leaders and masses worshipped in pre-exilic times. Meticulous planning based upon visible leadership and sanctified by the deity of reporting is proclaimed to be the only key to the success of the anticipated restoration venture. Focusing inter alia on the occupation and total reconstruction and restoration of the land, judicial system, commerce and industry and on the reestablishment of the society with its culture and cult, the main issue is clearly that restoration and reconstruction can take place only under flawless autochthonous leadership. It would appear as if the Chronicler realised the necessity and therefore accepted the responsibility to devise a master plan based upon a biased one-sided portrayal of historical David as theopolitical leader par excellence (cf. 1 Chr. 11-29).

In an effort to cover all exigencies that leader and/or led could face during the anticipated process of restoration and reconstruction, the Chronicler's modus operandi involved the assignation of specific characteristics and attributes to God as ruler par excellence of the past, the present and the future. However, a theopolitical reading shows that in Chronicles the deity is underplayed in relation to autochthonous leadership. In fact, the true deity of 1 and 2 Chronicles is successful political leadership a la the example of deified visible Davidic leadership. Thus biased reporting determines fiats for leaders and led of the present and the future to understand and accept the deity of the day - only, the deity of the day is unnamed and hidden in biased reporting.

Apropos to the above, the postulate of this article is that the essence of Chronicles is not a portrayal of Yahweh, the God of Judah and also of Davidic leadership. The crux of this historiography is to present an elect audience with options of specific types of leadership in a particular religious and dogmatic atmosphere and thus to ensure a successful restoration and reconstruction process. Pretending to advocate loyal devotion of a particular deity, Chronicles unfold as a paradigm for leadership through the deification of politics. However, the politics propounded are not that of the visible Davidic leadership, but of individuals/groups that remain in the background. Were they perhaps the Levites of Hebron and the cult officials of the Jerusalem Temple? While their politics 
may have differed, both groups manipulated the deity and visible Davidic leadership to lend credence to their politics and to reach their own objectives. Historiographical reporting's fiat to gauge the quality of visible leadership is a Davidite's measure of devotion to a Deity whose attributes and demands are manipulated to suit the politics of the puppet masters controlling leaders and led, namely the unnamed politicians planning the return of the mundane.

\subsection{The mundane}

\subsubsection{Definition of the concept mundane/masses/faceless masses}

In this article the terms mundane, masses and/or faceless masses will be used alternately and without preference. For the purposes of this article the above terms are understood to refer to a group of people imbued by common intents who contrive to attain common objectives albeit they often, but not necessarily, lack the required knowledge, experience, expertise and training. According to this premise a faceless member of the masses is defined as an unidentified individual who forms part of a group. By taking part in mass action, this individual identifies with the expectations of the group and therefore feels content to share in demands for and expectations of involvement in targeted spheres. However, when speaking in terms of a nation, then this definition should be augmented by adding that the term nation comprises a faceless, unidentified mass of people inhabiting a particular country and adhering to the rule of specific leadership. It is important that even among the faceless there are the exceptions, namely those individuals that attain renown or notoriety in a particular field because of distinctive feats or because of certain unsavoury exploits.

\subsubsection{The mute, faceless, ageless masses of society}

In his La Rebelión de la Masas or Der Aufstand der Massen (1930/1933) the Spanish philosopher, José Ortega y Gasset, avers that the mass person, overconfident and arrogant, occupies the civilised world as if it is a hitherto uninhabited paradise. In his description of the rising masses and its correlate, the mass state, he avers that this phenomenon threatens the essence and the existence of the entire civilised world. Ortega y Gasset argues that the cause of this threat lies in overpopulation, the inability of the education system and of the mentors to educate the youth. He defines youth as the products of an overpopulated world with no interest in the norms, the mores, the morals of civilisation. In a mass society they can be equated with the children of a modern Hameln blindly following a pied piper. However, in these final years of the twentieth century, it would appear as if Ortega y Gasset's observations leave much to be desired. In the first instance, although the masses are mute and faceless, they do not comprise only the young, but a member of the masses ostensibly can only operate as and when forming part of mass action. It is 
important that a nation, any group could be termed mute, faceless and ageless. Only the exceptions have a face or a voice. Also, age is not important to the Chronicler, because he does not remark on the age of the mundane on the very rare occasions that they do act, but the impression is created that masses indicate mature and concerned leaders of the people (cf. inter alia $1 \mathrm{Chr}$. 12; $2 \mathrm{Chr}$. $33: 21-25)$.

Furthermore, in concurrence with Ortega y Gasset it is one of the observations of this article that the mundane of Chronicles seemingly possesses no historical awareness.

\subsubsection{The classless masses in Chronicles}

Chronicles portray a nation as a classless society comprising faceless individuals from the northern and the southern tribes that were initially united by David into a nation, the Israelites (1 Chr. 12). Eventually, due to the expansion wars of David (cf. inter alia Hattingh, 1999), this nation would also include peoples like the Edomites (2 Chr. 25:5-16; cf. 2 Kings 14:7) and Jebusites (1 Chr. 11:4-9).

Although there appear to be a few exceptions like some of those born into the House of David, important cult officials and a few important soldiers and other state officials (1 Chr. 1-9), the nation/society described by the Chronicler is classless. This equality of a classless people is best illustrated by events on those rare occasions when no Davidite was found worthy to rule or was available to rule. Usually a hitherto unmentioned member of the faceless masses would then step forward and take over the command of the people (Asher, 1997:8-136; Japhet, 1993; Nel, 1991; 1997; cf. inter alia the history of Joash in 2 Chr. 24 and that of Amon in 2 Chr. 33:21-25). However, these instances provide such scant evidence that it is doubtful whether even Bauval and Hancock (1997) would succeed with a computer reconstruction of the historicity of these events.

\subsubsection{The people of Chronicles}

There are very few recorded incidences of mass activity in Chronicles. The principal examples are 1 Chronicles 12 (the portrayal of the unification of all Israel under the leadership of David) and 2 Chronicles 33:25 that recounts the revolution of the truly faceless am ha-aretz against the equally nameless assassins of Amon. Other examples, inter alia the Passover festival organised by Hezzekiah (2 Chr. 30-31) appear to be mass activities, but if analysed in context, it is evident that only certain elements of the Northern and the Southern Kingdoms were involved, i.e. the zealous devotees of a specific deity, namely Yahweh the God of Hezzekiah (cf. Japhet, 1993:933-973).

Although evidence pertaining to mass activities is fairly meagre, this should not be interpreted as evidence that the masses accepted the Davidic kings without any critique and/or objections. It is the contention of this article that the absence 
of recorded critique should be seen as evidence of the role of manipulation and biased reporting in historiography. However, albeit hidden beneath layers of biases, historiography cannot invariably evade the truth or hide the facts of history. Compare inter alia David's reaction to his welcome after the defeat and death of Absalom (2 Sam. 19:11-14). It is important that this significant event in David's life goes unreported in Chronicles. In accord with the hypothesis of this article, it is obvious that the reporting of this occurrence would have reflected negatively on the role of David as leader par excellence and would thus defer the creation of a paradigm for visible leadership.

Events like inter alia Hezzekiah's Passover (2 Chr. 30-31) and the move against Amon's assassins (2 Chr. 33:25), are further proof of historiography's wilful exposition and transformation of visible Davidic leadership into theopolitical leadership. The leadership of the faceless masses are judged and classified according to the historiographer(s) view of the required measure of dedication to the deity, and it would appear as if statesmanship was of no importance. However, it is important that the deity is the god of the cartographers of the future and not necessarily the Creator-God buried in layers of history.

The truly faceless who seemingly follow their leaders unthinking and without any murmur or audible complaints, the mundane of Chronicles has no character, shows no initiative. It is as if they do not exist at all. In fact, Chronicles is an excellent example of the notoriety of historiography in changing the dynamic life of a nation into a history of kings, soldiers and cult leaders. However, the Chronicler does not merely narrate, but has transformed the history of a people into a story about the best, the mediocre and the worst of Davidic kings. And in this process the existence of the faceless masses disappeared into an oblivion created by historiography. The evidence of the existence of an invisible leader corps also becomes increasingly evident as the history of the Davidic leaders unfold against the international events of the time (Asher, 1996). Yet, the faceless masses existed and even survived the ordeal of exile - despite the rule of the Davidites.

\subsection{Leadership}

Apropos to the above, history has proved beyond any doubt that the mundane always act under leadership of a person or a group. Therefore, even theopolitical leadership is tantamount to manipulation of the masses by the true leaders, albeit these true leaders are often - if not usually - indiscernible by the masses and even the reporting audience. In the case of theopolitical leadership, it is the postulate of this article that politicians usually provide a deity necessary for the exploitation and manipulation of the masses to benefit prerequisites of leadership at a particular moment in time. Power and self-enrichment are the major incentives in this process. 


\subsubsection{Definition of leadership}

For the purposes of this article leadership is defined as the impetus behind acts of the mundane. Leadership is conceived as a person, a group of people, a hierarchy, a bureaucracy imbued with authority to determine policies and actions on behalf of others (i.e. their followers) and who accepts the responsibilities of decision-making on behalf and for the benefit of the led. Therefore, leadership per se involves identification and delineation of leader and led (Burns, 1978). Bass and Avolio (1994:1-2) aver that good leadership goes beyond the importance of the leaders simply achieving objectives and maintaining quality relationships with their followers. While the led could be an institution, organisation, society, group or an undefined party of people massing together, their numbers are irrelevant. What is relevant and therefore very important, is that the success or the ineffectiveness of the leader is always also that of the led.

Worthy leadership is far-sighted and all encompassing. Embedded in any type of leadership should always be a vision, an ideal for the future. Successful leadership dare not cling changeless to the past and cannot be only engrossed in the present. It must always be able to selectively draw on the best and the worse of yesterday and today to meet the prerequisites of and thus ensure the success of tomorrow.

\subsubsection{Visible leadership of the mundane}

The onset of any mass action immediately gives rise to the need of recorders and observers to detect and to identify the leader or leaders, because where there is a group, there must be a leader or leaders. It is the presupposition of this study that leadership of the mundane always falls into two categories, viz. visible and invisible leadership.

When outsiders observe mass action in person or on television, the lasting impression is always that of swaying, faceless slogan chanters propelled by an identifiable leader or leaders. These visible leaders of the mundane are often referred to as ringleaders. It depends entirely upon the sympathies of the observers, whether this term is interpreted as derogatory or meritorious. The crucial question is whether these visible ringleaders are really in the vanguard. If they are, then one could conclude that their objectives are the same as that of the faceless masses. If they are not in the vanguard, what are their real position(s), importance and power-base? And, even more important, if the visible leaders are not the true leaders, can we identify the real leaders?

\subsubsection{Invisible leadership of the mundane}

According to the diagram at the beginning of this article, visible leadership forms part of leadership per se. However, this is a moot point, because if they 
are no leaders, do they not then form part of the manipulated masses? However, because their very obvious visibility forces them into a leadership role, the inference is that they are leaders by virtue of the objectives of the authentic leadership corps. These invisible leaders' anonymity and obscurity are their most potent tools in controlling the mundane. The greater the anonymity of the authentic leaders, the greater their ability to control the faceless masses. Apropos to the premise of this article their invisibility and anonymity reduce their responsibility. At the same time it increases the culpability of the visible leaders for the behaviour or misbehaviour of the mundane.

The frightening implication of this postulate is that nothing is what it appears to be. Ringleaders are not leaders and the mundane are motiveless and unaware of the real compulsion behind their actions. The authentic leaders could hide among the faceless masses and then the mundane is not the unconditionally led. Although it may appear to outsiders - and even to the masses themselves - that the very visible ringleaders spearhead them, the latter exercise no decisive authoritative leadership. In fact, they are the manipulated par excellence. With all the attention riveted on the ringleaders, silently and undetected the undocumented, unseen and secretive bona fide leaders of the faceless masses inexorably steer the visible, violent and well-documented history with its Ersatz leadership on an unknown course.

Should this be transposed to the Davidic history in Chronicles, then even David could be termed a ringleader. He was even manipulated by Samuel into usurping Saul's kingship (cf. 1 inter alia 1 Sam. 16; 1 Chr. 11:1-3; 12). Although he was always very visible to the masses, he knew as much about what happened on his country's borders as the Levites would allow him to know (cf. inter alia Hauer, 1963). If not David and the Davidites, who then were the real leader(s) of Israel? The Levites from Hebron? The Zadokite Jerusalem priesthood? This is a moot question that will be discussed in more detail in future follow-up articles.

\section{Conclusion}

The study of theopolitics is opening yet undreamed of vistas concerning especially value systems and the norms and morals of leadership. This is important not only for religious texts, but also for social sciences per se. Theopolitics is such an all-encompassing subject that no one article and no single book can hope to cover all the relevant aspects of this interesting science.

As far as the present study of theopolitics is concerned, it would appear as if leadership forms the nucleus of theopolitics and that effective leadership depends upon the quality of the invisible leadership corps. However, the frightening implication of this premise is that nothing is as it appears to be and that nobody can be trusted to present a true reflection of reality. Therefore, the 
identity as well as an estimate of the validity and value of leadership is not to be found in the eye of the beholder, because he/she forms part of the manipulated led. And the reporters and their biases are in the service of the invisible leaders. Can we or should we then oppose or support theopolitical leadership? This hypothesis will be developed further in forthcoming articles in which an attempt will be made to find answers for many of the questions in this article. At this point in time theopolitics is still a virtually unexplored stretch of land, therefore, the objective of this article is not to provide an immutable interpretation of the concept theopolitics, but to initiate a South African debate in an attempt to determine the dynamics of this intricate process.

\section{Bibliography}

ABDALATI, H. 1975. Islam in focus. Indianapolis : American Trust Publications.

AMIT, Y. 1994. Literature in the service of politics. (In Reventlow, H.G. et al., eds. Politics and theopolitics in the Bible and postbiblical literature. Sheffield : Sheffield Academic Press. p. 28-40.)

ARCHER, J. 1996. The Fourth Estate. London : BCA.

ASHER, A.H.E. 1996. Judah and her neighbours in the seventh century BC. Pretoria : Unisa. (D.Litt et Phil Thesis.)

BASS, B.M. \& AVOLIO, B.J. 1994. Improving organizational effectiveness through transformational leadership. London : SAGE.

BAUVAL, R. \& HANCOCK, G. 1997. Keeper of Genesis. A quest for the hidden legacy of mankind. London : Mandarin.

BEN-SASSON, H.H., ed. 1976. A history of the Jewish people. Cambridge : Harvard University Press.

Biblia Hebraica Stuttgartensia. Stuttgart: Deutsche Bibelgesellschaft.

BRIGHT, J. 1972. A history of Israel. London : SCM.

BURNS, J.M. 1978. Leadership. New York : Harper \& Row.

CHILDS, B.S. 1985. Old Testament theology in a canonical context. London : SCM.

CLEMENTS, R.E., ed. 1989. The world of ancient Israel. Sociological, anthropological and political perspectives. Cambridge : Cambridge University Press.

DONALDSON, D.M. 1970. Theocracy: "God Rule". The Muslim World, LX(2):103-108.

ELTON, G.R. 1967. The practice of history. Sydney : Sydney University Press.

GARDNER, L. 1996. Boodline of the Holy Grail. Dorset : ELEMENT.

HATTINGH, H.B. 1999. Dawid in diens van Jahwe se verbondsaktiwiteit ter wille van Israel: 'n Perspektief op die konteks van 2 Samuel 7. Durban-Umlazi Campus : University of Zululand. (M.Th. dissertation.)

HAUER, C.E. 1963. Who was Zadok? Journal of Biblical Literature, 82:1-14.

HERZL, T. 1895/1946. The Jewish state. Translator: Sylvie D'Avignor. London : Rita Searl.

HOFFMAN, Y. 1994. Politics and theopolitics in the Bible and postbiblical literature. (In Reventlow, H.G. et al., eds. Sheffield : Sheffield Academic Press. p. 85-99.)

Holy Bible. Contemporary English Version. 1996. Goodwood : Bible Society of South Africa. JAPHET, S. 1993. I and II Chronicles. A commentary. London : SCM.

KEDDIE, N.R., ed. 1972. Scholars, saints and Sufis. Muslim religious institutions since 1500. Berkeley \& Los Angeles : University of California Press.

LE ROUX, C. du P. 1986. Die teologiese grondslag van die moderne Islamitiese staat in teorie en praktyk. Johannesburg : Rand Afrikaans University. (D. Litt et Phil thesis.)

LE ROUX, C.J.B. \& NEL, H.W. 1998. Radical Islamic fundamentalism in South Africa. An exploratory study. Journal for Contemporary History, 23(2):1-24, Dec. 
MacINTYRE, R.R. 1981. Saudi Arabia. The politics of Islamic reassertion. London : Croom Helm.

NEL, H.W. 1991. Die Kronis se uitbeelding van die teokrasie in 1 en 2 Kronieke. Pretoria : Unisa. (D.Litt et Phil proefskrif.)

NEL, H.W. 1992. The Chronicler's perspective of God in 1 and 2 Chronicles. Journal for Semitics, 4:98-113.

NEL, H.W. 1997. Theopolitics in the Davidic monarchal system. A pilot study. In die Skriflig, 31(4):421-436, Des.

ORTEGA Y GASSET, J. 1930/1933. Der Aufstand der Massen. Translated from Spanish by Helene Weyl. Stuttgart : Deutsche Verlags-Anstalt.

REVENTLOW, H.G., HOFFMAN, Y. \& UFFENHEIMER, B., eds. 1994. Politics and theopolitics in the Bible and postbiblical literature. Sheffield : Sheffield Academic Press.

ROTH, C. 1977. A history of the Jews from earliest times through the Six Days War. Rev. ed. New York : Schocken Books.

SMITH, M. 1984. Jewish religious life in the Persian period. (In Davies, W.D. \& Finkelstein, L., eds. The Cambridge history of Judaism. Vol. 1. Cambridge : Cambridge University Press.)

SNYMAN, G.F. 1991. Biblical hermeneutics and reception theory: the authority of Biblical texts and the Chroniclers interpretation of the sacred story of the ark. Pretoria : Unisa. (D.Th thesis.)

SOGGIN A.J. 1985. A history of Israel from the beginning to the Bar Kochba Revolt AD 135. London : SCM. 